\title{
自動二輪車の低速走行におけるライダーの挙動に関する研究1 〜熟練度による差異の分析〜
}

\author{
横井元治 ${ }^{2} ，$ 青木和夫 ${ }^{2} ，$ 堀内邦雄 ${ }^{3}$
}

\begin{abstract}
Narrow road low-speed riding (hereinafter, referred to as narrow-bridge riding) is a key technique for motorcycle riders to improve their fundamental riding ability. However, since mechanism of narrowbridge riding has not been clarified, motorcycle instructors are teaching this technique based only on their experience. This research had two purposes. One was to reveal the difference in the movements of riders and frame body comparing beginner and expert riders. The second was to make use of the obtained results for improving motorcycle riding instruction. We conducted a narrow-bridge riding test on 14 riders with different experience levels. As a result, we found three characteristic operations and movements by expert riders who could continue narrow-bridge riding at low-speed: (1) Large steering angle. (2) Fewer head roll movements, and (3) Use of vertical load of handles. These results suggest that keeping head rolling movements to a minimum by using the vertical load of the handle subsequently improves riders' narrowbridge riding skill.. The knowledge about the mechanism of skillful narrow-bridge riding should be useful in a new teaching method.
\end{abstract}

自動二輪車（以下，二輪車）における狭路極低速走行（以下，一本橋走行）は基礎運転能力向上のために 必須の技術であるが，その訓練方法は指導者の経験に基づいたものになっており，動作メカニズムは解明さ れていない，そこで本研究では，初級群と熟練群におけるライダーの動作と車体の挙動の差を明確にし，一 本橋走行の指導向上につなげていくことを目的とした．実験は熟練度の異なる14名のライダーにおいて，二 輪車を用い走行制限の高い狭路での走行を実施した。その結果，継続した低速での走行を可能としていた熟 練群は，一本橋走行中に，(1) 大きなハンドル転舵角領域を活用し走行する.（2）頭部のロール動作を少なく している.（3）ハンドルの上下方向の荷重を活用し走行する．という3つの特徴的な操作抢よび動作が確認で きた．以上の結果から，ハンドルの上下方向の荷重を活用して頭部ロールを抑制することが，一本橋走行技 術の向上につながり, 新たな指導法として有効である可能性が示唆された.

(キーワード : 二輪車, 低速走行, 頭部ロール，角速度，角加速度，ハンドル荷重）

\section{1.はじめに}

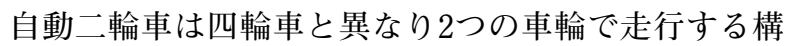
造上の特性から，低速走行の場合にはジャイロ効果が得 られなくなり前方への運動エネルギーや慣性力も小さく なるため，ロール方向の安定性が低くなることが一般的 に知られている1). すなわち，低速の走行ではバランス を取ることが難しい。

道路交通法では狭路極低速走行（以下，一本橋走行）

1 受付：2016年7月18日 受理：2017年6月26日

2 日本大学大学院 理工学研究科

Graduate School of Science and Technology, Nihon University

3 工学院大学 先進工学部

School of Advanced Engineering, Kogakuin University
を運転能力判断の基準として二輪車免許取得の実技講習 に採用している2) ことからも，この低速のバランス走行 は二輪車走行の重要な基礎能力であり，安全かつ的確な 操作の判断材料として適当である.

一方，二輪車の一本橋走行における指導の現場では， 費やすことのできる時間が限られているため，免許取得 に必要な基準タイムを達成できるためのテクニックの指 導が中心になっている. このことは指導要領3) やアドバ イス集など4) からも明らかであり，ライダーが二輪車の 車体（以下，車体）の挙動をどのようにして感じ取り， どのような行動をする必要があるかを述べているものは 無い。このことから，現在の教習所教育においては一本 橋走行に打けるライダー挙動についての教育が十分に実 施されず，ライダーと車体がどのようにバランス状態を 作り上げているのかをライダー自身が十分に理解できて 
いないことが課題と考える.

熟練度の違いによる乗車技量の差の確認に関しての先 行研究としては, 乗馬騎手の熟練度の違いにおける人体 の挙動の比較をTeradaが扔こなっている5).この中で, 「常歩（なみあし）」という馬の歩く速度域で頭部の前後 方向および上下方向の加速度と, $\mathrm{EMG}$ (直腹筋, 春柱起 立筋，大外転筋）の測定をおこない，初心者の特徵とし て頭部の前後方向に度数分布の分散が見られた $(p<.10)$ と述べている. しかしながら, 乗馬という上下方向の動 的な運動を伴う状態の解析であるため，二輪車の低速走 行でのバランス状態と同様に判断を扔こなうことは困難 と考える.

次に二輪車の低速走行に関する挙動の先行研究として は，車体のメカニズムに関する研究はおこなわれている. 例えば二輪車の操舵機構を検討した辻井らは, 前後輪の タイヤの接地点と車体の重心位置に着目し, 重力ベクト ルとの関係性を使って安定性を評価した ${ }^{6)}$ 。一方，バラ ンスを失うポイントのひとつと考えられるライダーの動 作や操作に着目した研究は少ない。横森らが取り組んだ 低速直進走行時のライダーの直立安定制御7)の中では, 最低走行速度 $5.0 \mathrm{~km} / \mathrm{h}$ の条件で小型自動二輪車の走行実 験を実施し, 直進打よび直立の安定のためにライダー が車体をバンクさせた（傾かせた）後にハンドルの転舵 操作動作が発生していることを示した。また田中らは スクーター型の電動二輪車の低速走行時（最低走行速度 $5.0 \mathrm{~km} / \mathrm{h})$ には，転舵角とヨーレイトの最大值が大きく なり, 高速走行時よりもライダーに大きな挙動が発生し ていることを報告している8.

ただし，いずれの実験に扔いても，ライダーが走行状 態でバランスを失った結果として発生するふらつきと， その後の修正の影響について検討を行った実験であり， ライダーがバランスを失わないためにどのような操作や 動作が必要になるのかについては検討されていない.

そこで本研究では, 車体ーライダー系が安定となる動 作メカニズムに基づいた指導法に応用していくため, 熟 練ライダーの動作メカニズムを明らかにすることを目的 とした。

\section{2. 実験方法}

\section{2-1. 実験概要}

熟練度の異なるライダーにおける二輪車走行比較実験 を行った，走行に対し制限を設けるため，一本橋を使用 した，実験協力者は二輪車に乗車した状態で，水平な路
面に設置された一本橋を5回走行した，走行に当たり， ライダーは着座姿勢かつ教習所などで習う正しい姿勢を とること，及びなるべく長い時間一本橋上で走行をおこ なうことを教示した。

測定項目は，ライダーの一本橋走行所要時間（以下走 行タイム)，車体及びライダーの角速度，そしてハンド ルの転舵角とハンドルに生じる荷重とした。

\section{2-2. コースレイアウト}

\section{A) コース概要}

実験は平坦なアスファルト路面に後述の一本橋を設置 し走行を行った．本実験の走行路のレイアウトを図1に 示す．橋の手前 $4.0 \mathrm{~m}$ の所にスタート地点を設定し，一本 橋に乗る前に助走区間で車体を安定させられるようにし た. また, 一本橋走行終了後 $3.0 \mathrm{~m}$ の走行区間を設け, ゴー ル地点で停止し安全確認後, 次の行動に移った.

\section{B) 二輪車走行用一本橋}

実験に用いた一本橋は，罒 2 に示す幅 $0.3 \mathrm{~m}$ ，長さ $15.0 \mathrm{~m}$ ，高さ $0.05 \mathrm{~m}$ のアルミニウム製のものを使用した (自動車教習所などで使用しているものと同形状)。なお，

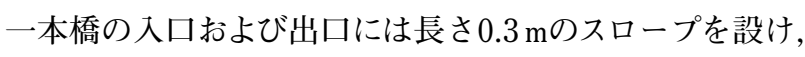
ライダーおよび車体への急激な挙動変化が発生しないよ うした。

\section{2-3. 実験協力者（ライダー）}

ライダーは，大型二輪免許取得者男性14名とした。 ラ

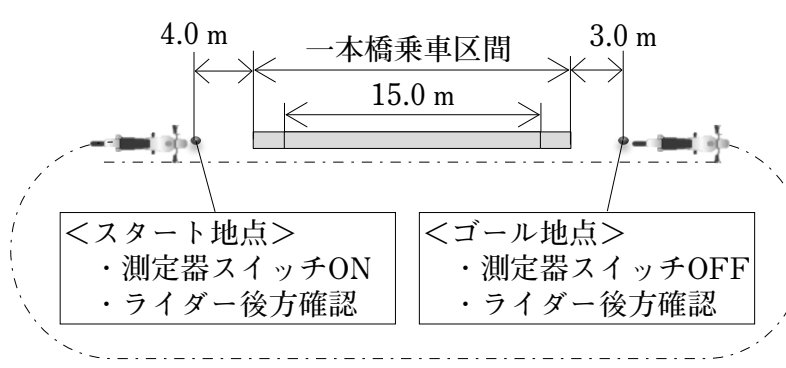

図1実験コースレイアウト

Fig. 1 Course of the test riding.

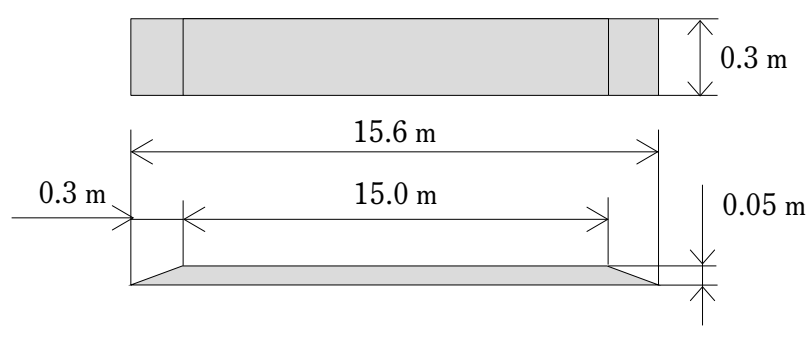

図2 二輪車走行用一本橋

Fig. 2 Narrow bridge of motorcycle riding. 
イダーの平均年齢は $30.6 \pm 7.2$ 歳, 免許取得からの平均保 有年数は9.1土4.9年であった。 なお，教習所での訓練以 降一本橋走行の経験の無い者7名, 企業内のインストラ クターとして一本橋走行の訓練経験のある者7名とした. 各ライダーには事前に本研究の目的，方法，個人情報に 関する秘密の保持などの主旨を説明し，参加は自由であ ることと自分の意思で中止できる内容を文章および口頭 で説明をおこない，文書による同意を得て実験を行った。 また，実験に際しては十分に安全への配慮をおこなって 実施した。 なお，本研究は工学院大学における倫理審査 委員会の承認を得た（承認番号H27-7）。

\section{2-4. 実験装置}

\section{A) 二輪車}

二輪車は大型自動二輪教習に打いて多く使用されてい る，排気量750 ccの自動二輪車CB750（Honda製）を用い た. なお，走行上の安全を確保するため, 以下の条件を 満たす二輪車を選択した。

・定期的（2回以上／週）に一本橋走行での使用をおこ なっていること

・転倒時のリスク軽減用のバンパを装備していること(大 型自動二輪教習所と同仕様)

また，実験ごとに二輪車の特性差が生じないようにす るため，1台の二輪車に交代で乗車した．

\section{B) 角速度センサ}

ライダーと車体の挙動測定には小型ワイヤレスジャイ ロセンサTSND 121 (ATR-Promotions inc.製，以下ジャ イロセンサ）を用いた。取り付け位置は次の3箇所とし た (図3)。(1)車体中央上部(2)ライダー背部（胸背部プロ テクタ上, 第3胸椎棘突起点部付近) (3)ライダー頭部（へ ルメット上の後頭部最後部)

測定はそれぞれについてのピッチ角，ロール角，ヨー 角の3軸の角速度を行った（図4)。なお，サンプリン グ周波数は $50 \mathrm{~Hz}$, 角速度の測定レンジは $\pm 250 \mathrm{deg} / \mathrm{s}$ と した.

C) ポテンショメータ

ライダーのハンドル転舵角の測定にはポテンショメー タHSM 12 (栄通信工業製)を用いた。 センサの取り付け については，回転部がハンドル回転中央部ステムホール に取り付くように，センサ本体を実験用二輪車のタンク 上部から専用の治具で確実に固定を行った。なお，サン プリング周波数は $100 \mathrm{~Hz}$ とした。

\section{D) 歪みゲージ}

ライダーのハンドル転舵操作時の上下方向及び前後方 向の荷重について，左右それぞれの分担荷重を測定する

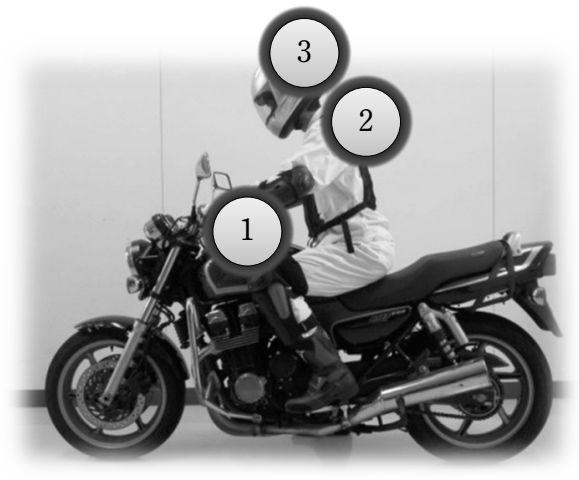

図3 角速度測定点

Fig. 3 Measurement points of the angular velocity.

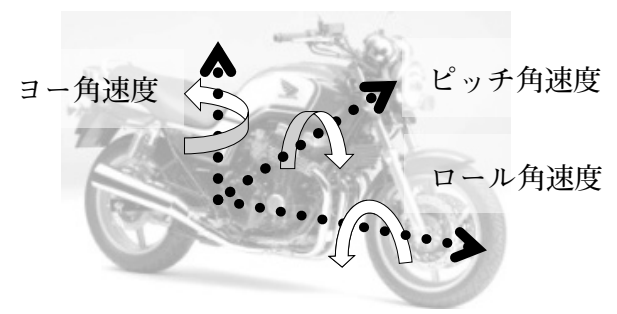

図4 センサの測定方向

Fig. 4 Measurement direction of the sensor.

ため，歪みゲージ：FLK2-11（東京計測研究所製）を用 いた。取り付け位置は実験用二輪車の左右ハンドルパイ プ付け根付近に地面と垂直または水平となるよう接着郕 で確実に固定した．荷重の測定にはS/N比を高くするた めに 2 アクティブゲージ法を用いた。 ハンドル上下方向 の荷重測定用は，ハンドル付け根の上部と下部の歪み ゲージで測定した。 ハンドル左側に下方，ハンドル右側 に上方の力が発生する状態をプラス荷重とし，ハンドル 左側に上方，ハンドル右側に下方の力が発生する状態を マイナス荷重と設定した。また，ハンドル前後方向の荷 重測定は，ハンドル付け根の前部と後部の歪みゲージで 測定した。 ハンドル右側に前方，ハンドル左側に後方の 力が発生する状態をプラス荷重とし，ハンドル左側に前 方，ハンドル右側に後方の力が発生する状態をマイナス 荷重と設定した。なお，サンプリング周波数は $100 \mathrm{~Hz}$ した.

\section{2-5. 解析方法}

ライダーは二輪車に乗車した状態で，水平な路面に設 置された一本橋を走行し，橋から落ちることなく走行し たものを有効データとした．5回の走行データのうち最 もパフォーマンスの高かった（長時間一本橋の上で走行 できた）ものを測定データとして採用した．解析には測 定スタートの 1.0 秒後からゴール手前 0.5 秒前までのデー 


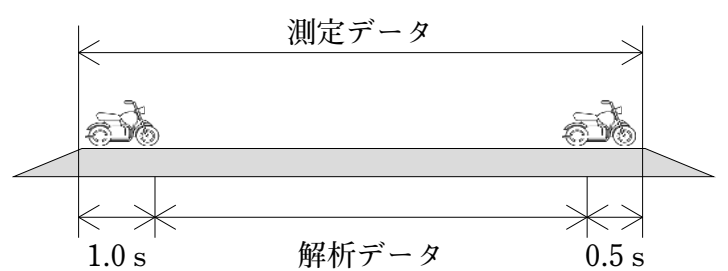

図5 挙動データ解析区間

Fig. 5 Analysis interval of the movements.

タを用いた. また，取得したデータは 3 点移動平均で平 滑化を行った.

車体とライダーにおける挙動の特性比較に関しては, それぞれの角速度データ，ハンドル転舵角データ及び八 ンドル荷重データの頻度分布を算出し, 解析を行った. 本実験において全てのデータは0を中心にほぼ左右対称 で分布していた。 そのため，ピーク值を比較することで 特徵を抽出する事とした。 また，測定データに対して， 位相ずれなしの状態を基準として, サンプリング周波数 から 0.02 秒ごとに頭部角速度の波形をずらし，相互相関 係数を算出した. なお，すべての統計処理には有限会社 オーエムエス出版発行の「Statcel 3」を使用した.

\section{3. 結 果}

\section{3-1. 走行パフォーマンス}

ライダーの一本橋走行パフォーマンスのうち，下位， 上位各4名をそれぞれ初級群および熟練群とし，残りの 6名を中間群と分類した。 それぞれのパフォーマンスは, 初級群 $15.5 \pm 2.0 \mathrm{~s}$, 中間群 $27.8 \pm 7.5 \mathrm{~s}$, 熟練群 $61.5 \pm$ 22.0 sであった（図6)。また，各群をTukey-Kramer法で 多重比較検定を行った結果, 初級群と熟練群および, 中 間群と熟練群で有意差がみられた $(p<.05)$. このことから， 初級群や中間群に比べ熟練群は有意にパフォーマンスが 良かったと判断できる.

\section{3-2. 車体ロール角速度, 角加速度}

困7a），b）に各群における車体ロール角速度の頻度分 布を示す. グラフからいずれの群も全員 $0 \mathrm{deg} / \mathrm{s}$ 付近にピー クが発生しており, 初級群と熟練群ともに大きな車体ロー ル角速度が発生していないことが確認できた，両群での 挙動の差異を確認するため, 各ライダーの標準偏差に ついてマン・ホイットニーのU検定を行った. 結果, 中 央值 (四分位範囲) の值は初級群4.18 (3.74-4.22) deg/s, 熟練群5.60 (5.48-5.66) deg/sで初級群の車体における角 速度の分布が有意に広かった $(p<.05$, 表 1$)$. すなわち

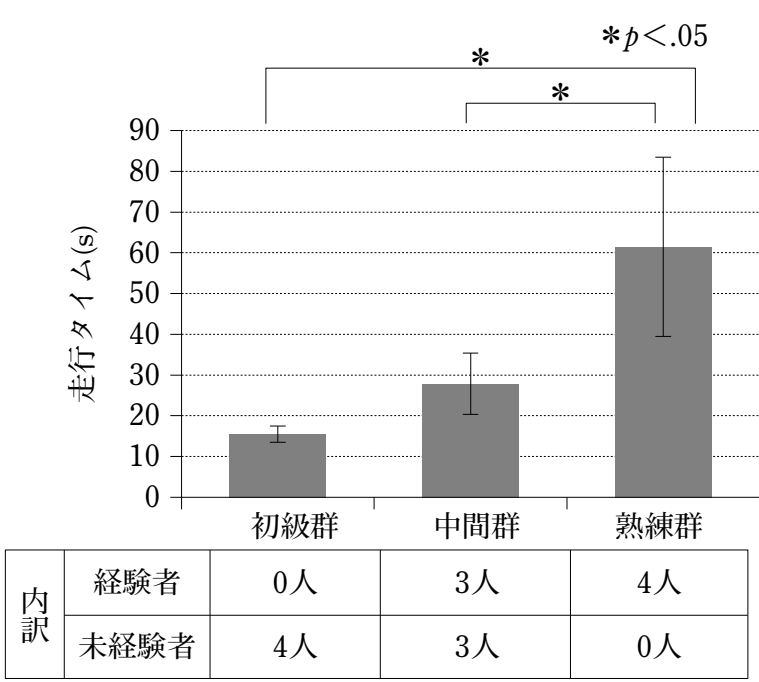

図6 各群のパフォーマンス比較

Fig. 6 Riding time on narrow bridge.

熟練群は初級群に比べ大きな角速度を多く発生させてい ることが確認できた.

また，得られた各ライダーのデータから車体ロール角 加速度を求め, 両群の比較を行った (図7c)，d））。結果， 初級群と熟練群の間に分布の差異は確認できなかった。

\section{3-3．頭部ロール角速度，角加速度}

図7e，f）に各群における頭部ロール角速度の頻度分 布を示す. 同様に両群での挙動の差異を確認するため, それぞれについて各ライダーの標準偏差に対しマン・ホ イットニーのU検定を行った. 結果, 両群の分布に対し て有意差を確認できなかった（表1）。また同様に，各 ライダーのデータから頭部ロール角加速度を求め，差異 の検討を行った (図 $7 \mathrm{~g}) ， \mathrm{~h})$ )。結果，中央值（四分位範 囲) の值は初級群171.29 (150.94-188.52) deg/s ，熟練群 111.85 (90.06-123.00) deg/s 2 で初級群の頭部における角 加速度の分布が広いことが示された $(p<.05)$. すなわ ち初級群は熟練群に比べ大きな頭部ロール角加速度を多 く発生させていることが確認できた.

\section{3-4. ハンドル転舵角}

困7i），j）に各群におけるハンドル転舵角の頻度分布を 示す．同様に両群の差異の確認として各ライダーの転舵 角測定データの標準偏差についてマン・ホイットニーの $U$ 検定を実施した。結果，中央值（四分位範囲）の值は 初級群3.07 (2.27-3.73) deg，熟練群9.11 (6.99-11.29) deg となり, 熟練群のほうが有意に広い分布を示した $(p<.05$, 表1).すなおち熟練群は初級群に比ベハンドルを左右に 転舵した状態で走行していることが確認できた. 


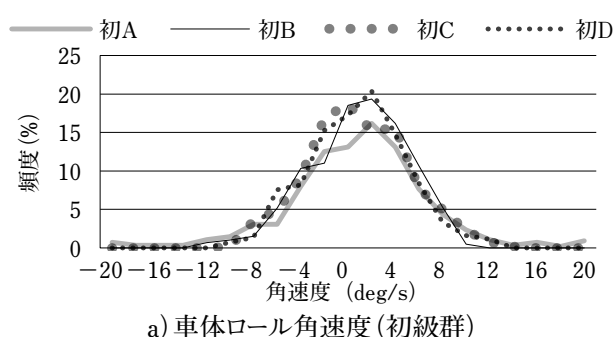

a) Roll angular velocity of frame body (beginners)

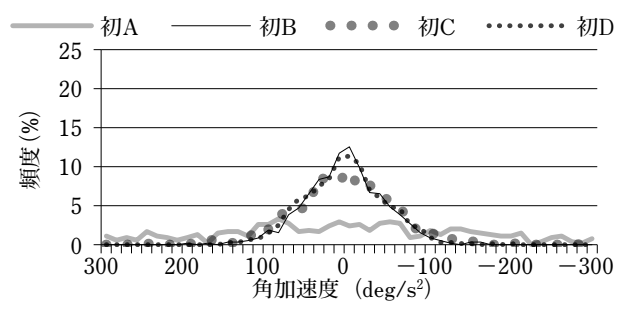

c) 車体口ール角加速度 (初級群)

c) Roll angular $\mathrm{v}$ acceleration of frame body (beginners)

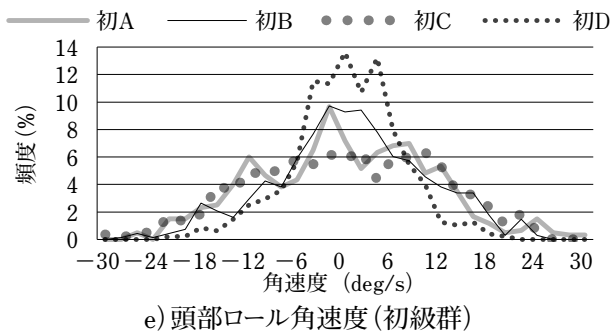

e) Roll angular velocity of rider's head (beginners)

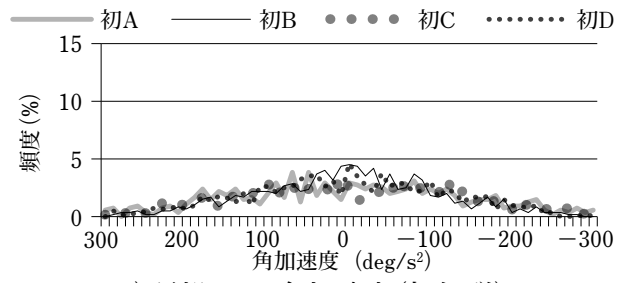

g) 頭部口ール角加速度 (初級群)

g) Roll angular v acceleration of rider's head (beginners)

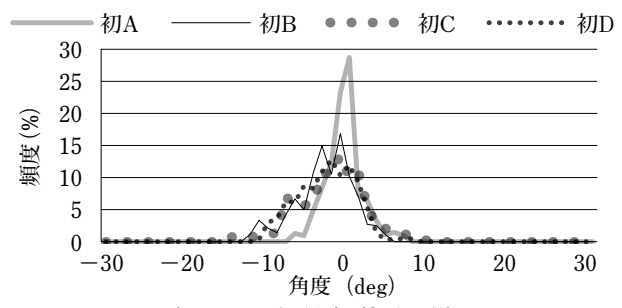

i) ハンドル転舵角 (初級群)

i) Angle of steering (beginners)

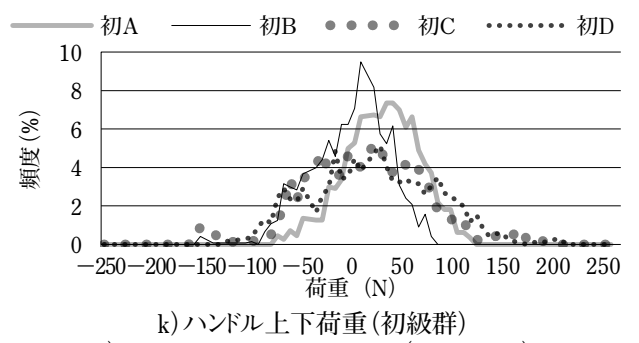

k) Vertical load of steering (beginners)

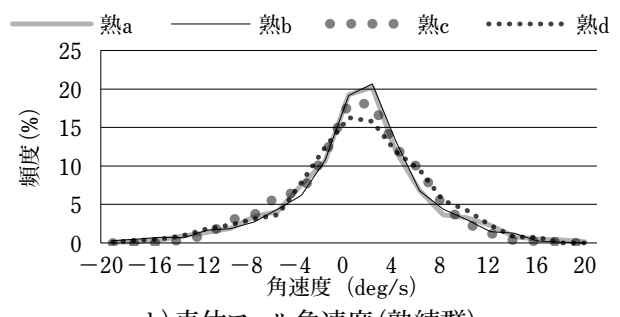

b) 車体ロール角速度 (熟練群)

b) Roll angular velocity of frame body (experts)

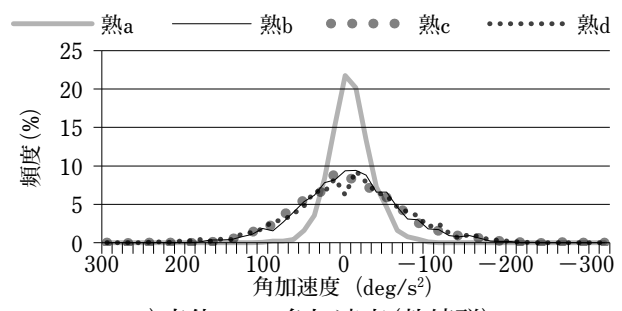

d) 車体口ール角加速度 (熟練群)

d) Roll angular v acceleration of frame body (experts)

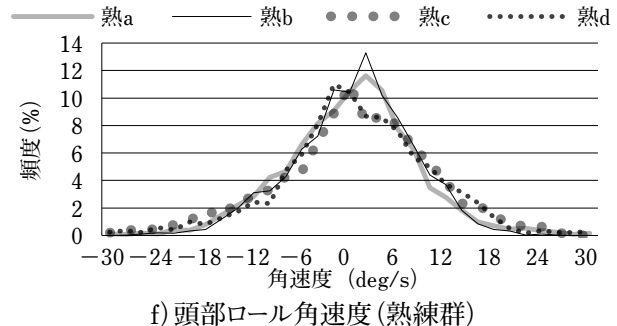

f) Roll angular velocity of rider's head (experts)

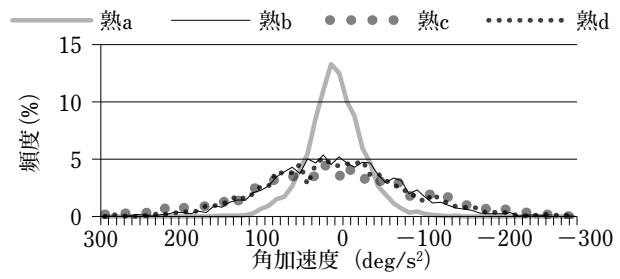

h) 頭部ロール角加速度 (熟練群)

h) Roll angular v acceleration of rider's head (experts)

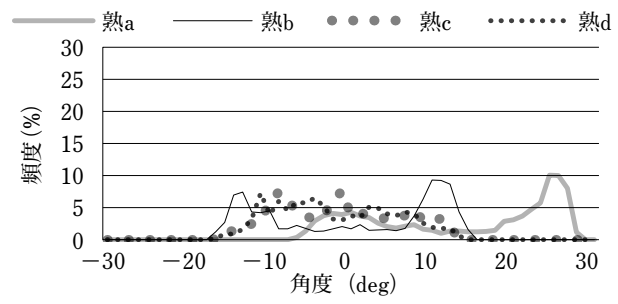

j)ハンドル転舵角 (熟練群)

j) Angle of steering (experts)

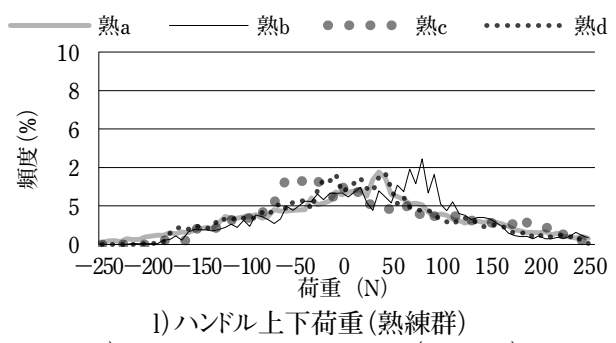

l) Vertical load of steering (experts)

図7 各頻度分布

Fig. 7 Distribution of frequency from the riding tests. 


\section{3-5. ハンドル上下荷重}

図7k)，l）にライダーごとのハンドル上下荷重の頻度 分布を示す. 同様に両群の差異の確認として各ライダー の転舵角測定データの標準偏差についてマン・ホイッ トニーのU検定を実施した. 結果, 中央值 (四分位範 囲）の值は初級群47.79 (29.07-58.78) N，熟練群94.39 (91.97-98.02) Nとなり，熟練群のほうが有意に広い分 布を示した $(p<.05$, 表1). すなわち, 熟練群は初級群 に比ベハンドル上下方向の荷重を多く使用している状態 で一本橋走行を扢こなっていることが確認できた。

\section{3-6. ハンドル上下荷重と頭部ロール角速度の関 係性}

頭部ロールとハンドル上下荷重の関係を確認するため, 初級群，熟練群それぞれについて相関係数が最大になる 頭部ロール角速度発生に対するハンドル上下荷重発生の 位相遅れ条件とその相関係数を求めた。 また，それぞれ のライダーの相関係数について両群での差異を確認する ため, マン・ホイットニーのU検定を行った (表2). 結 果, 中央值 (四分位範囲) の值は熟練群0.39 (0.32-0.41), 初級群0.63（0.56-0.70）で初級群のほうが有意に高い相

表1 各測定項目の標準偏差における中央值と四分位範囲

Tab. 1 Median and interquartile range of each experimental results.

\begin{tabular}{|c|c|c|c|}
\hline $\begin{array}{c}\text { 車体ロール角速度 } \\
(\mathrm{deg} / \mathrm{s})\end{array}$ & $\begin{array}{c}4.18 \\
(3.74-4.22)\end{array}$ & $\begin{array}{c}\text { 初級群 } \\
(5.48-50 \text { 群 }\end{array}$ & $p$ \\
\hline $\begin{array}{c}\text { 車体ロール角加速度 } \\
\left(\mathrm{deg} / \mathrm{s}^{2}\right)\end{array}$ & $\begin{array}{c}45.17 \\
(39.78-95.40)\end{array}$ & $\begin{array}{c}50.39 \\
(41.61-52.49)\end{array}$ & $\mathrm{N} . \mathrm{S}$. \\
\hline $\begin{array}{c}\text { 頭部ロール角速度 } \\
(\mathrm{deg} / \mathrm{s})\end{array}$ & $\begin{array}{c}11.26 \\
(10.41-11.94)\end{array}$ & $\begin{array}{c}8.96 \\
(8.14-9.57)\end{array}$ & $\mathrm{N} . \mathrm{S}$. \\
\hline $\begin{array}{c}\text { 頭部ロール角加速度 } \\
\left(\mathrm{deg} / \mathrm{s}^{2}\right)\end{array}$ & $\begin{array}{c}171.29 \\
(150.94-188.52)\end{array}$ & $\begin{array}{c}111.85 \\
(90.06-123.00)\end{array}$ & $<.05$ \\
\hline $\begin{array}{c}\text { ハンル転舵角 } \\
(\mathrm{deg})\end{array}$ & $\begin{array}{c}3.07 \\
(2.27-3.73)\end{array}$ & $\begin{array}{c}9.11 \\
(6.99-11.29)\end{array}$ & $<.05$ \\
\hline $\begin{array}{c}\text { ハント荷重 } \\
(\mathrm{N})\end{array}$ & $\begin{array}{c}47.79 \\
(29.07-58.78)\end{array}$ & $\begin{array}{c}94.39 \\
(91.97-98.02)\end{array}$ & $<.05$ \\
\hline
\end{tabular}

表2 ハンドル上下荷重と頭部ロール角速度の相関

Tab. 2 Correlation coefficient between vertical load of steering and roll angular velocity of rider's head.

\begin{tabular}{|c|c|c|}
\hline & $\begin{array}{c}r \text { 中央值 } \\
\text { (四分位範囲) }\end{array}$ & $\begin{array}{c}\text { 頭部ロールに対する } \\
\text { ハンドル上下荷重の } \\
\text { 位相遅れ }(\mathrm{s})\end{array}$ \\
\hline 熟練群 & $0.39(0.32-0.41)$ & $0.19 \pm 0.11$ \\
\hline 初級群 & $0.63(0.56-0.70)$ & $0.08 \pm 0.04$ \\
\hline
\end{tabular}

関を示していることが確認できた $(p<.05)$. また，初 級群の相関係数が最大となる位相遅れ条件は $0.08 \pm 0.04 \mathrm{~s}$ であり，頭部ロール発生とほぼ同時または直後に荷重が 高くなった. 以上のことから, 初級群は頭部ロールと同時, もしくは頭部ロールが起きた直後にハンドルに荷重がか かっていることが明確になった。

\section{3-7. ハンドル上下荷重と車体ロール角速度の関 係性}

ハンドル上下荷重と車体ロール角速度の関係を確認す るため，それぞれについて位相を変え最大となる相関係 数を求めた. 結果, 表 3 に示すように初級群 $r=0.71$, 熟

表3 ハンドル上下荷重と車体ロール角速度の相関

Tab. 3 Correlation coefficient between vertical load of steering and roll angular velocity of frame body.

\begin{tabular}{|c|c|c|}
\hline & $r$ 平均 \pm s.d. & $\begin{array}{c}\text { 車体ロールに対する } \\
\text { ハンドル上下荷重の } \\
\text { 位相遅れ (s) }\end{array}$ \\
\hline 熟練群 & $-0.71 \pm 0.06$ & $-0.13 \pm 0.01$ \\
\hline 初級群 & $0.71 \pm 0.04$ & $-0.20 \pm 0.05$ \\
\hline
\end{tabular}
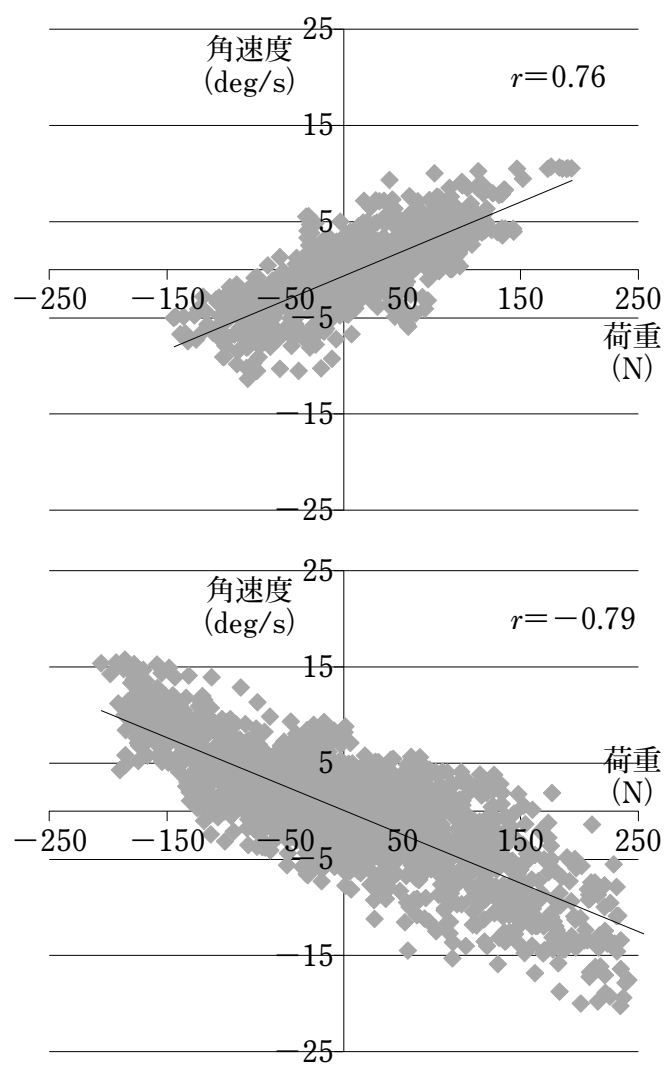

図8 ハンドル上下荷重と車体ロール角速度の相関例（上段： 初級群, 下段 : 熟練群)

Fig. 8 Correlation coefficient between vertical load of steering and roll angular velocity of frame body. 
練群 $r=-0.71$ となり，ともに高い相関があることが確認 できた．ただし，その分布は図8の例に示すように車体 のロール発生方向と位相遅れのタイミングは異なってい ることが確認できた。熟練群では，ハンドル上下荷重が 発生した $0.13 \mathrm{~s}$ 後に転舵と逆方向の車体ロール角速度が 発生し, 一方, 初級群は車体のロール角速度が発生した $0.20 \mathrm{~s}$ 後に転舵と同方向にハンドル上下荷重が発生して いることが確認できた。

\section{3-8. 頭部ロール角速度と頭部ロール角加速度の 関係性}

頭部ロール角速度と頭部ロール角加速度の関係を確認 するためそれぞれについて相関係数を求めた. 結果, 初 級群 $r=0.56 \pm 0.11$, 熟練群 $r=0.50 \pm 0.06$ となり, とも に相関があることが確認できた。

\section{4. 考 察}

ここまで得られた結果から，一本橋走行におけるライ ダー挙動のメカニズムについての検討を行った. 二輪車 で安定して一本橋走行をおこなうためには，車体一ライ ダー系について,

1) バランスを失わないこと

2）バランスを失った際に素早く修復できること

が条件となる。この中でも特に1)の「バランスを失わ ないこと」は安定走行の前提にあたる部分であり, 重要 な要素である，本研究においては，「バランスを失わな いこと」に関しての検討を行うこととした. 車体一ライダー 系においてバランスを保つためには，路面と接地してい る車体の運動量 $\mathrm{p}=\mathrm{mv}$ を大さしないことが必要となる. そこで車体のロール角速度の発生を抑える方法を導き出 すための考察を行った。

\section{4-1． 転舵角使用の差について}

熟練群は初級群に比べ有意にハンドル転舵角が大きな 状態で走行していることが確認できた。一本橋走行にお いてハンドルを転舵させることは二輪車の前輪が一本橋 上を蛇行することになり，その結果同じ一本橋上でも走 行距離を伸ばすことができる効果がある。 また，ハンド 儿操作によってキャスタ角を活用し, 起きあがり力を発 生させていることも知られている ${ }^{9)}$ ささらに，ハンドル を左右に転舵させることにより, 二輪車の前後輪が一直 線上に並ばず，前後輪の基底面が増加する. このことか ら車体一ライダー系の重心点を前後輪基底面の鉛直上に とどめやすくなる効果があると考えられる.

\section{4-2. 車体ロール角速度とハンドル上下荷重の関 係性について}

本実験の結果より，熟練群は初級群に比べ有意にハン ドルの上下方向に荷重をかけた状態で走行している事が 確認できた。 また，初級群，熟練群ともにハンドル上下 荷重は車体のロール角速度発生と相関が高くなっている ことが確認できた。ただし，この相関に関してロールの 発生方向は初級群では荷重と同方向，熟練群では荷重と 逆方向で異なる傾向を示していた.

熟練者に見られたハンドルの上下荷重と逆方向のロー ル角速度は，先述したキャスタ角を要する二輪車のハン ドル転舵操作に伴い発生するロール特性9) と判断できる. 一方，初級群はハンドル上下荷重と同方向のロールが発 生していることが確認でき，熟練者の動作とは異なる. すなわち倒れる方向の角速度の発生となり，バランスを 失う原因のひとつと考えられる.

\section{4-3. ハンドル上下荷重と頭部ロール角速度の関 係性について}

各ライダーのハンドル上下荷重に対する他パラメタの 関係性とその位相差の発生について確認を行った。結果， 初級群の頭部ロールがハンドル上下荷重の発生より前の タイミングで，ハンドル荷重と同方向に発生しているこ とが確認できた。このことから初級群は頭部ロールが発 生したときに，ハンドルへ荷重を発生させているという ことを示している。，一方，熟練群においては，ハンドル 上下荷重と頭部ロール角速度との相関は低いことが確認 できた.

以上から頭部ロール角速度の発生がハンドルの上下方 向の荷重となり，結果，車体ロール角速度を発生させる という初級群特有のバランスの乱れのメカニズムを発見 することができた。そしてこのバランスの乱れを抑制す るため，前方に進む速度を下げずに走行することで，車 体一ライダー系のバランスを確保していることが考えら れる. ただし，この方法は低速で走行することと相反し ており，低速走行に対し限界が生じることとなる.

熟練群は初級群において発生していたバランスの乱れ が発生していないことが確認できた. バランスの乱れを 発生させないことで，安定した走行状態を保つことができ， パフォーマンスの向上につなげていると考えられる.

\section{4-4. 頭部ロール角速度と頭部ロール角加速度の 関係性について}

頭部ロール角速度成分および頭部ロール角加速度成分 
に着目すると，初級群，熟練群ともに両成分間における 中程度の相関を確認することができた，車体ーライダー 系の重心点は一般的に車体中央付近のエンジンとライダー の慰部との間に位置して抢り，ライダーの頭部はこの重 心点から離れているため慣性モーメントの影響が大きく なる。したがって頭部の大きなロール角加速度が発生す ることで頭部ロール角速度も大きくなると考えられる。

本実験では，熟練群は頭部の大きな角加速度を発生さ せる急激な頭部動作が初級群に比べ有意に少ないことが 確認できた，車体ーライダー系のバランスの乱れの原因 となる頭部ロール角加速度の発生そのものを少なくする ことで，車体のロール角速度も発生せず，速度が低い状 態でも安定して走行が可能となっていることが推測できた.

\section{4-5. 熟練群の頭部ロール角加速度の抑制について}

熟練群ライダーは初級群に比べ頭部ロール角加速度が 低くなっていることを確認できた，また，ハンドル上下 方向の荷重頻度に着目すると, 熟練群が有意に高い頻度 となっていることを確認でき, 熟練群はハンドルの上下 方向に荷重をかけた状態で走行している事が示された. 従来, 一本橋走行に打いては, 車体を安定させるために 膝で車体を挟み込むニーグリップ動作を提唱している3 3 (3) が，二輪車の乗車姿勢の特性上，ニーグリップ動作のみ では上半身, 特に膝よりも前方に位置している頭部のロー 儿動作を抑制させることが困難である (図9左図)，従っ て, 熟練群は頭部よりも前方に配置されているハンドル 部分を用い, 両膝と両手の 4 点支持をおこなうことによっ て, 頭部を含むライダー上半身の安定性を確保している と推測された，その結果，ハンドルの上下方向の荷重が 初級群に比べ有意に大きくなっているということが考え られる (図9右図)。また，熟練群はハンドルが転舵を多 く活用していることも確認できた，ハンドル転舵状態は 先述のように後輪の基底面が増加車体によりロール方向 への抵抗力が上がっているため上下方向に荷重をかけて もバランスの乱れが発生しづらく, 効果的に荷重をかけ られるようになっていると考えられる。

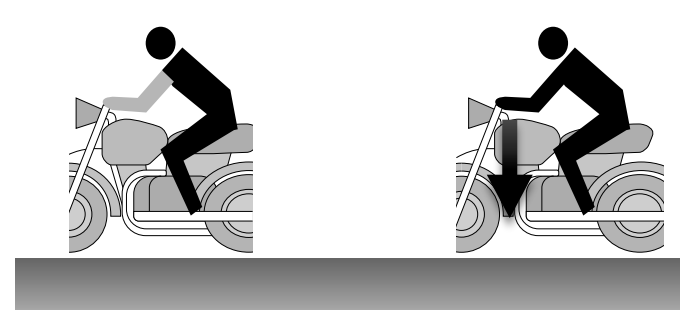

図9 ライディングポジションと頭部の位置関係

Fig. 9 Layout of riding position and rider's head.

\section{5. 結 論}

従来明確になっていなかった，極低速走行におけるバ ランスの維持および乱れの発生に対するライダーの操作 および動作について，パフォーマンスの高かった熟練群 の一本橋走行から3つの特徵を確認することができた.

(1)大きなハンドル転舵角領域を活用し走行する

(2)頭部の急激なロール動作を少なくしている

(3)ハンドルの上下方向の荷重を活用し走行する

また, これらの熟練群における特徵的な挙動から，八 ンドルの上下方向の荷重を活用した頭部ロール角加速度 の抑制という，新たな知見を得ることが出来，今後の一 本橋走行指導の新たな方向性を示すことができた.

今回得られた指導の方向性をもとに，効果的に運転能 力を向上できる指導法を作り出していき，活用を実施し ていきたいと考える。 その活用と共に，今後は初級群か ら熟練群に成長していくまでの過程に現れてくる，それ ぞれの段階ごとの特徵的な動きのメカニズムを明確にし， 学習の効果を上げられるようにしていきたいと考える.

\section{参考文献}

1）関根太郎, 他：長江啓泰のバイクに乗るための $\mathrm{ABC}$, 啓 正社, 2015

2）警察庁：運転免許技能試験実施基準, 警察庁交通局, 2014

3）ホンダ安全運転普及本部：SAFETY RIDING 2輪テキ スト (指導者用), 服部印刷, 2004

4）門名秀樹 : オートバイ操縦法,ナツメ社, pp.96-97, 1982

5) Terada: Comparison of Head Movement and EMG Activity of Muscles between Advanced and Novice Horseback Riders at Different Gaits, Journal of Equine Science, 11 (4), pp.83-90, 2000

6) 辻井栄一郎, 他：二輪操舵システムの開発, YAMAHA MOTOR TECHNICAL REVIEW, 第47号, pp.67-73, 2011

7）横森求, 他 : 低速直進走行時のオートバイのライダーに よる操作特性, 日本機械学会論文集 (C編), 57 (540), 1991

8）田中穣, 他：低速時における二輪車ライダーの挙動分析の 実験, 日本大学理工学部 学術講演会論文集, pp.895-896, 2013

9）和歌山利宏 : ライダーのためのバイク基礎工学, グラン プリ出版, 1987

\section{著者情報}

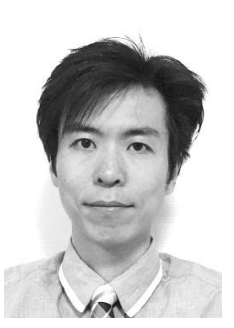

横井元治（よこいもとはる，正会員，連絡 著者)

1998年日本大学大学院理工学研究科医療. 福祉工学専攻博士前期課程修了, 2016年 同後期課程修了 (工学博士).

日本人間工学会認定人間工学専門家機構副 機構長，自動車技術会会員，専門はモビリ ティの乗員に関する人間工学研究.

連絡先 : mot227@mb.infoweb.ne.jp 
青木和夫（あおきかずお，正会員）

日本大学理工学部特任教授, 保健学博士, 認定人間工学専門家.

1979年東京大学大学院医学系研究科保健 学専攻博士課程単位取得退学, 東京大学医 学部助手, 日本大学理工学部助教授, 教授 を経て2017年より現職.

日本人間工学会理事. 日本公衆衛生学会, 日本ストレス学会，日本運動疫学会などの 会員. 医療や健康・福祉に関連した人間工学の研究に従事.
堀内邦雄（ほりうちくにお，正会員）

工学院大学先進工学部機械理工学科准教 授, 博士 (工学).

1983年電気通信大学電気通信学部機械工 学科卒業. 2000年日本大学大学院理工学 研究科博士後期課程医療・福祉工学専攻修 了. 1983年テルモ株式会社入社. 2006年 工学院大学グローバルエンジニアリング学 部機械創造工学科助教授を経て2015年よ

り現職.

日本人間工学会，日本生体医工学会，日本人工臓器学会，日 本医療機器学会などの会員. 医用工学, 人間工学の研究に 従事. 